\title{
Histidinaemia in mouse and man
}

\author{
GRAHAME BULFIELD and HENRIK KACSER \\ From the Department of Genetics, University of Edinburgh
}

\begin{abstract}
Bulfield, G., and Kacser, H. (1974). Archives of Disease in Childhood, 49, 545. Histidinaemia in mouse and man. A recently discovered mutant in the mouse was found to have very low levels of histidase. It is an autosomal recessive. In its enzymic and metabolic properties it appears to be a homologue of human histidinaemia. While the homozygous mouse mutants show no overt abnormalities, offspring of histidinaemic mothers display a balance defect resulting in circling behaviour. This is associated with vestibular damage during in utero development. Mental retardation caused by human maternal phenylketonuria may have a similar aetiology.
\end{abstract}

There are well recognized advantages in studying animal models in the investigation of human diseases. The increasing number of disorders in man which are reported to have a genetic basis (McKusick, 1971; Raine, 1972) makes it desirable to find and investigate animal homologues with the same genic lesions. The genetically most investigated laboratory mammal is the mouse, with over 500 known mutants (Green, 1966; Searle, 1973). Some of these mouse mutants show disorders similar to human syndromes such as maturity-onset diabetes (Mayer, 1960), the pituitary dwarf (Elftman and Wegelius, 1959), and ChediakHigashi syndrome (Padgett et al., 1967). Only a few, however, have been shown to be enzymically identical in the two species. These are albinism (tyrosinase: Coleman, 1962), acatalasaemia (catalase: Feinstein, 1970), and glycogen storage disease type VIa (phosphorylase kinase: Huijing, 1970).

Most of the classical inborn errors of metabolism have therefore yet to be shown in a mouse mutant. One of the reasons for this may be the lack of a concerted effort to screen the relevant biochemical parameters. In an attempt to produce such evidence, a project was established based on automated column chromatography and automated enzyme assays. The first major abnormality detected by this programme-histidinaemia-is discussed here.

In brief, the histidinaemia displayed in the mouse is caused by an autosomal recessive gene (designated his) resulting in low histidase activity with less than $5 \%$ of normal (Kacser, Bulfield, and Wallace, 1973). As a consequence, there are large accumulations of

Received 15 November 1973. histidine and its derivatives. The enzymic and metabolic changes in both mouse and human mutants appear to be the same. In addition, maternal histidinaemia in the mouse has a teratogenic effect on the developing inner ear which results in abnormal behaviour of the affected offspring. These findings may be relevant to the aetiology of human histidinaemia.

\section{Genetic and metabolic characterization}

Histidinaemic mice have high levels of histidine in urine, liver, plasma, brain, and skin, and high concentrations of imidazole derivatives in urine and more moderate ones in liver. Table I summarizes the quantitative observations.

Any of the metabolite pools in all the tissues studied gave a consistent nonoverlapping difference between 'normal' and 'high' values. Classification of histidinaemic individuals is therefore possible on any one of the tissue determinations. A further consequence of low histidase activity is a reduced concentration of the product of the reaction, i.e. urocanic acid. This is evident in the skin, as seen in Table II, which shows the comparison of the two classes in the skin of 7-day-old mice.

Considerable variation was found in the absolute histidine levels within the high (histidinaemic) group. This variation, however, was in general reflected in all the tissues of a single animal. Fig. 1-3 show these relations. It should be pointed out that the plasma, liver, and brain values represent the metabolites at the same time point, while urines were collected days (and sometimes weeks) before sacrifice of the animal. This may account for the poorer correlation in Fig. 3. 
TABLE I

Biochemical characterization. Mean values at 7 weeks

\begin{tabular}{|c|c|c|c|}
\hline Tissue & Histidinaemic & Normal & $\mathbf{R}=\mathbf{H} / \mathbf{N}$ \\
\hline $\begin{array}{l}\text { Liver } \\
\text { Histidase } \\
\text { Histidine } \\
\text { Ac histidine } \\
\quad+\text { Im pyruvatef } \\
\text { Im lactate } \\
\text { Im acetate }\end{array}$ & $\begin{array}{l}0 \cdot 013 \\
20 \cdot 9 \\
\\
0 \cdot 111 \\
0 \cdot 102 \\
0 \cdot 017\end{array}$ & $\begin{array}{r}0.280 \\
0.880 \\
0.0082 \\
0.0069 \\
<0.0044\end{array}$ & $\begin{array}{c}0 \cdot 046 \\
23 \cdot 7 \\
\\
13 \cdot 5 \\
14 \cdot 8 \\
>3 \cdot 7\end{array}$ \\
\hline $\begin{array}{l}\text { Urine } \\
\text { Histidine } \\
\text { Ac histidine } \\
\quad \text { + Im pyruvatet } \\
\text { Im lactate } \\
\text { Im acetate }\end{array}$ & $\begin{array}{l}0 \cdot 86 \\
3 \cdot 19 \\
1 \cdot 21 \\
1 \cdot 29\end{array}$ & $\begin{array}{l}0.04 \\
\\
0.11 \\
0.07 \\
0.05\end{array}$ & $\begin{array}{l}21 \cdot 5 \\
29 \cdot 0 \\
17 \cdot 3 \\
25 \cdot 8\end{array}$ \\
\hline $\begin{array}{l}\text { Plasma } \\
\text { Histidine } \\
\text { Ac histidine } \\
\quad \text { + Im pyruvatef } \\
\text { Im lactate } \\
\text { Im acetate }\end{array}$ & $\begin{array}{l}3 \cdot 30 \\
0 \cdot 016 \\
0 \cdot 012 \\
0.008\end{array}$ & $\begin{aligned} & 0.115 \\
& <0.0008 \\
< & 0.001 \\
< & 0.001\end{aligned}$ & $\begin{array}{r}28.7 \\
>20.0 \\
>12.0 \\
>8.0\end{array}$ \\
\hline $\begin{array}{l}\text { Brain } \\
\text { Histidine } \\
\text { Ac histidine } \\
\quad \text { + Im pyruvatet } \\
\text { Im lactate } \\
\text { Im acetate }\end{array}$ & $\begin{array}{c}2 \cdot 16 \\
0.0044 \\
0 \cdot 0204 \\
<0 \cdot 004\end{array}$ & $\begin{array}{r}0.169 \\
<0.0006 \\
<0.0007 \\
<0.0006\end{array}$ & $\begin{array}{r}12 \cdot 8 \\
>7 \cdot 3 \\
>29 \cdot 1 \\
-\end{array}$ \\
\hline
\end{tabular}

Note: All values are the means of between 5-10 animals. Liver and brain metabolites: $\mu \mathrm{mol} / \mathrm{g}$ wet tissue. Plasma and urine metabolites: $\mu \mathrm{mol} / \mathrm{ml}$. All determinations by column chromatography and ninhydrin or Pauly reaction, respectively.

*Histidase (E.C. 4.3.1.3) activity was determined by the appearance of urocanic acid at $277 \mathrm{~nm}$. The assay system was 65 $\mathrm{mmol} / 1$. phosphate buffer $p \mathrm{H} 9 \cdot 4,5 \mathrm{mmol} / 1$. reduced glutathione, 133 $\mathrm{mmol} / \mathrm{l}$. L-histidine $\mathrm{HCl}, 0.05 \mathrm{ml}$ enzyme, final volumn $1 \mathrm{ml}$. The liver was extracted in a Tri-R homogenizer $3: 1 \mathrm{v} / \mathrm{w}$ with a solution of $0.25 \mathrm{~mol} / 1$. sucrose, $1 \mathrm{mmol} / 1$. EDTA sodium salt, $1 \mathrm{mmol} / 1$. dithiothreitol, $50 \mathrm{mmol} / 1$. tris- $\mathrm{HCl}(p \mathrm{H} \mathrm{7} \cdot 4)$. The homogenate was centrifuged at $60,000 \mathrm{~g}_{\mathrm{av}}$ and the supernatant used to assay histidase as $\mu \mathrm{mol}$ urocanate $\min ^{-1} \mathrm{~g}^{-1}$ at $30^{\circ} \mathrm{C}$.

IIn our buffer system these two substances are not completely resolved. The values reported are the sum of both. Im, imidazole.

Matings between histidinaemic animals produce exclusively histidinaemic offspring. Matings between known heterozygotes give an unambiguous $3: 1$ ratio of normals to histidinaemics (158:51; $\left.\chi^{2}=0.0399\right)$. From this it is evident that the his

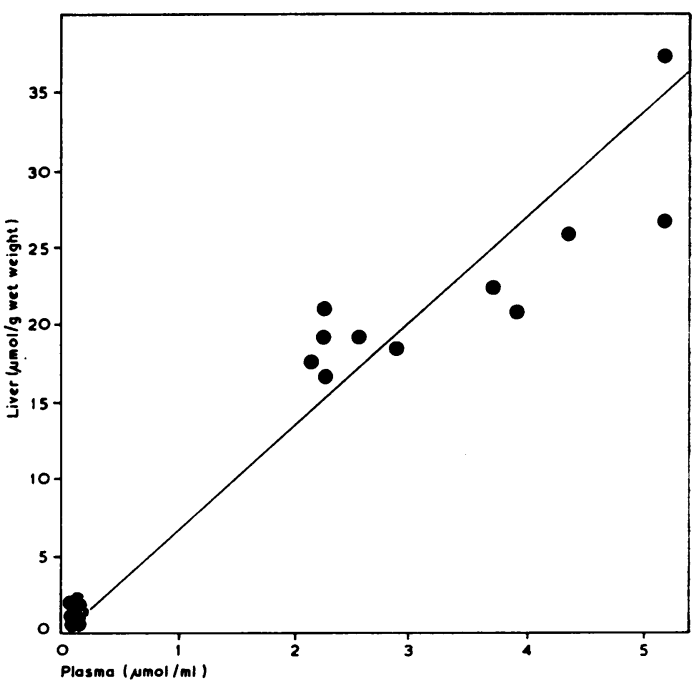

FIG. 1.-Relation of plasma histidine to liver histidine. The values ranging from 2 to $5 \mu \mathrm{mol} / \mathrm{ml}$ plasma represent individual histidinaemic animals. The cluster of low values is representative of the range for normal animals.

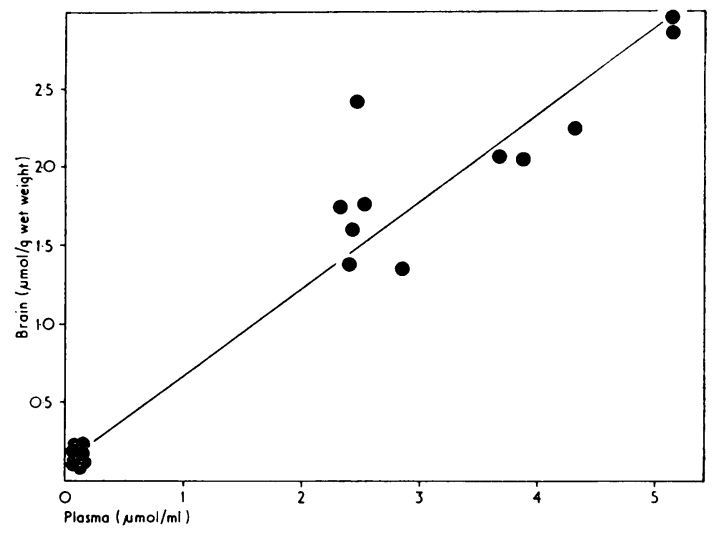

FIG. 2.-Relation of plasma histidine to brain histidine. Animals as for Fig. 1.

TABLE II

Histidine/urocanate relations in skin of littermates at 7 days of age

\begin{tabular}{l|c|c|c|c}
\hline \multirow{2}{*}{ Phenotype } & \multicolumn{2}{|c}{ Mean values } \\
\cline { 2 - 4 } & Histidase activity & Histidine & Urocanate & R = HIS/URO \\
\hline Histidinaemic & 0.0141 & 2.55 & 0.54 & $4 \cdot 72$ \\
Normal & 0.0493 & 0.89 & 1.20 & 0.74 \\
\hline
\end{tabular}

Note: Histidine and urocanate were determined by column chromatography and Pauly reaction. They are expressed as $\mu \mathrm{mol} / \mathrm{g}$ wet tissue. Histidase activity in $\mu \mathrm{mol}$ urocanate/min per $\mathrm{g}$ at $30^{\circ} \mathrm{C}$. The activities of the normals at 7 days are about $1 / 5$ of the adult (7-week) values. 


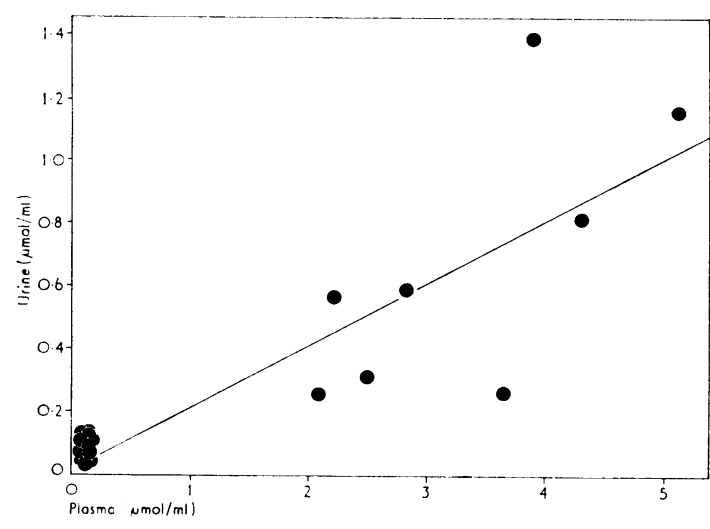

FIG. 3.-Relation of plasma histidine to urine histidine. Animals as for Fig. 1.

allele is recessive with complete penetrance and that the histidine values of heterozygous carriers fall within the normal range. This range is from 0.5 to $1 \cdot 1 \mu \mathrm{mol} / \mathrm{g}$ liver and contains animals of the two genotypes, homozygous normals and heterozygotes. These two genotypes were produced separately by appropriate matings and their histidine values were determined (Fig. 4). This shows that, though the
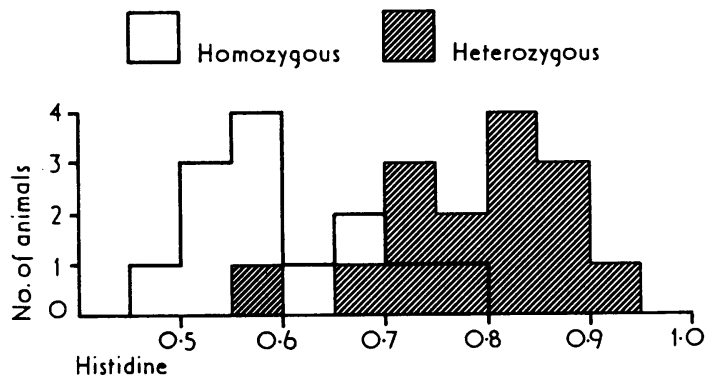

FIG. 4.-Liver histidine concentrations of known heterozygous and known homozygous normal animals. values are overlapping, there is a small but significant difference in mean values between homozygous normals and heterozygotes. Loading tests can distinguish the two genotypes. Addition of $6 \%$ histidine to the normal mouse diet (Dixon's FFG/LAC) when given to heterozygotes for 4 days raises the urine histidine and imidazoles to levels equal to, or above, those of histidinaemics. Normal homozygotes show little or no rise.

In many human recessive metabolic disorders, a normal substrate concentration in heterozygotes is associated with approximately half the enzyme activity compared with the normal homozygotes (Harris, 1970). This is also the case with histidase activity in mouse liver. As expected, there are three classes of activity which segregate 1:2:1 from heterozygous crosses, with the intermediate class having values about half-way between the other two. All known heterozygotes had enzyme activities in this intermediate range, though the male distributions showed some overlap. Table III shows the enzyme activities of a number of males and females matched for age, with their associated histidine levels. This shows that almost complete dominance at the histidine level is accompanied by intermediacy at the enzyme level. The small but significantly higher heterozygote levels show that there is no 'threshold' at one-half the enzyme concentration. This observation is in agreement with general considerations of the nature of multienzyme systems (Kacser and Burns, 1973).

\section{Comparison with human data}

The plasma concentrations of 51 and $1 \cdot 77 \mathrm{mg} / 100$ $\mathrm{ml}$ for the two mouse phenotypes, respectively, can be directly compared to the ranges reported for human subjects of 5 to 25 and $0.4-3.0 \mathrm{mg} / 100 \mathrm{ml}$. Other mouse data can be compared with the corresponding human evidence as far as published reports make this possible (Table IV). From this

TABLE III

Comparison of genotypes for liver histidase and histidine

\begin{tabular}{|c|c|c|c|c|}
\hline & \multicolumn{2}{|c|}{ Females $($ no. $=7$ ) } & \multicolumn{2}{|c|}{ Males (no. $=5$ ) } \\
\hline & Histidase activity & $\begin{array}{c}\text { Histidine } \\
\text { concentration }\end{array}$ & Histidase activity & $\begin{array}{c}\text { Histidine } \\
\text { concentration }\end{array}$ \\
\hline $\begin{array}{l}\text { Normal homozygotes } \\
\text { Heterozygotes } \\
\text { Mutant homozygotes }\end{array}$ & $\begin{array}{l}0 \cdot 364 \\
0 \cdot 181 \\
0 \cdot 015\end{array}$ & $\begin{array}{l}0 \cdot 736 \\
0 \cdot 832^{\star} \\
23 \cdot 1\end{array}$ & $\begin{array}{l}0 \cdot 236 \\
0 \cdot 139 \\
0 \cdot 013\end{array}$ & $\begin{array}{l}0 \cdot 625 \\
0 \cdot 840^{\star} \\
20 \cdot 1\end{array}$ \\
\hline
\end{tabular}

Note: Histidase and histidine units as in Table II.

$\star$ The mean differences of the heterozygote values from their respective normal homozygote values are significant at the 0.01 level. All other differences between the genotypes are significant at least at the 0.001 level. 
Bulfield and Kacser

TABLE IV

Comparison of mouse and human data

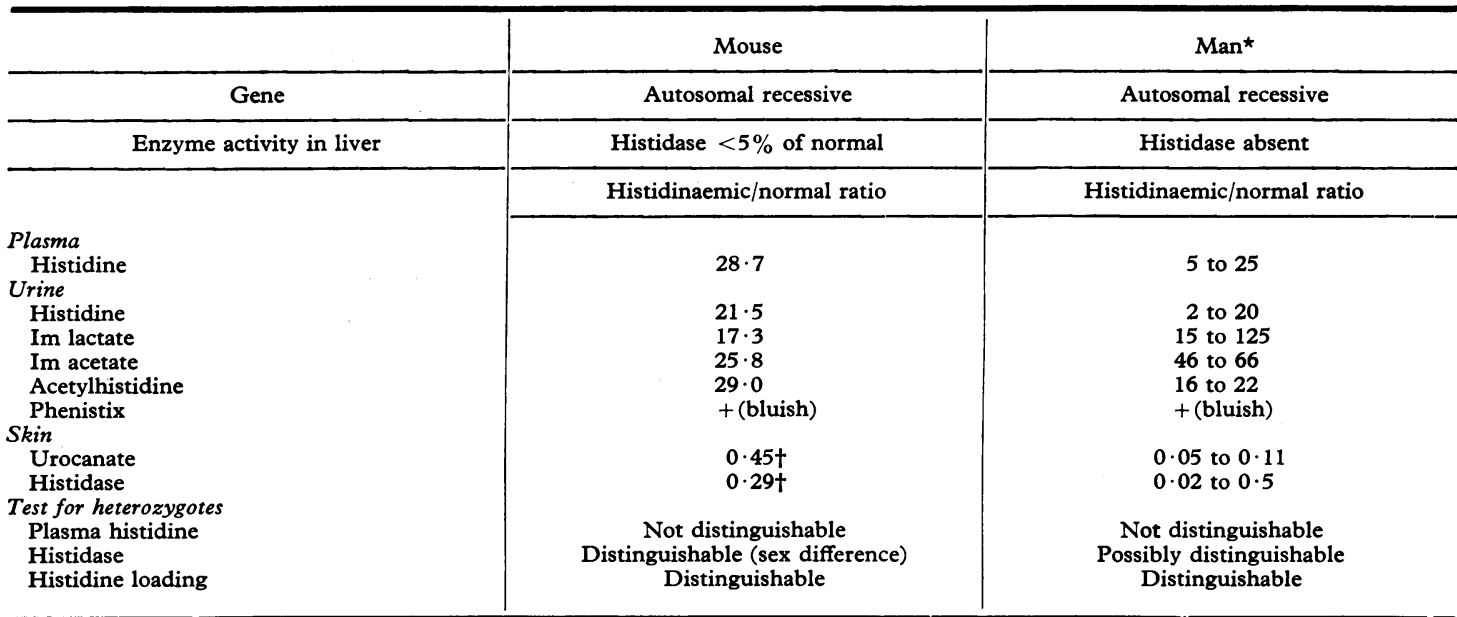

*The data for man were collated from published reports up to August 1973. (A copy of these references is available from H.K.) tThese data are for 7-day-old mice. All other values are for adults of 7 weeks.

comparison it appears that the two species have considerable metabolic similarities and it may be concluded that the mouse mutant is a homologue of the human disorder.

\section{Behavioural abnormality}

The first case of human histidinaemia, discovered in 1961 (Ghadimi, Partington, and Hunter, 1961), presented as speech retardation, and many cases described since show this symptom as well as low IQ (Neville et al., 1972), though a large proportion of histidinaemics show no such abnormality. It is therefore of interest that a behavioural abnormality was present in our mouse strain (Wallace, 1970). Its most obvious manifestation is a balance defect (circling behaviour and/or head tilting). Such animals can also be shown to differ from normals in their inability to swim, lack of disorientation after spinning, and poor maze learning ability.
The relation of the behavioural abnormality to the individual's metabolic (and hence genetic) condition is, however, not direct. Thus, among histidinaemic animals were found both balance defective and normal animals. Similarly, balance-defective animals can be either histidinaemic or metabolically normal. By setting up all possible crosses between histidinaemics (mutant homozygotes), carriers (heterozygotes), and normals (normal homozygotes), we have established that the balance defect syndrome appears only in animals born from histidinaemic mothers and does not depend on the offspring themselves being histidinaemic (Table V). The severity of the abnormality, however, is variable and can be barely detectable, at least by our tests. In general, an offspring which is itself histidinaemic is more severely affected than a nonhistidinaemic one (compare (a) and (b) in Table VI). There is also variation between individual matings in the

TABLE V

Numbers of balance-defective offspring from 3 types of matings where all parents were behaviourally normal animals

\begin{tabular}{|c|c|c|c|c|}
\hline \multicolumn{2}{|c|}{ Type of mating } & \multicolumn{2}{|c|}{ No. of offspring } & \multirow{2}{*}{$\begin{array}{c}\text { Proportion of } \\
\text { histidinaemic offspring }\end{array}$} \\
\hline Mother & Father & Balance defective & Normal & \\
\hline
\end{tabular}


TABLE VI

Classification of balance-defective offspring among animals from matings of histidinaemic female with (a) histidinaemic male and (b) normal homozygous male

\begin{tabular}{|c|c|c|c|}
\hline \multirow{2}{*}{ Mating } & \multicolumn{3}{|c|}{ Behaviour } \\
\hline & $\begin{array}{l}\text { Circling and } \\
\text { head tilting }\end{array}$ & $\begin{array}{l}\text { Head tilting } \\
\text { only }\end{array}$ & Normal \\
\hline (a) $\begin{array}{l}\text { C } 12 \\
\text { C } 38 \\
\text { C } 37 \\
\text { C } 36 \\
\text { C } 39 \\
\text { B } 14 \\
\text { B } 15\end{array}$ & $\begin{array}{l}0 \\
1 \\
3 \\
2 \\
7 \\
7 \\
9\end{array}$ & $\begin{array}{l}4 \\
2 \\
0 \\
1 \\
1 \\
0 \\
0\end{array}$ & $\begin{array}{r}5 \\
7 \\
10 \\
3 \\
1 \\
0 \\
0\end{array}$ \\
\hline Total (a) & 29 & 8 & 26 \\
\hline (b) $\begin{array}{l}\mathrm{P} 15 \\
\mathrm{P} 36 \\
\mathrm{P} 21\end{array}$ & $\begin{array}{l}0 \\
1 \\
0\end{array}$ & $\begin{array}{l}2 \\
0 \\
7\end{array}$ & $\begin{array}{l}2 \\
8 \\
3\end{array}$ \\
\hline Total (b) & 1 & 9 & 13 \\
\hline
\end{tabular}

proportion and severity of their affected offspring (Table VI).

In contrast, offspring from heterozygous mothers have never been observed as behaviourly abnormal even when they were histidinaemic (Table V). Nor have histidinaemic fathers when crossed to either normal or carrier mothers produced any balancedefective offspring. The balance defect is therefore seen to be conditional upon the metabolic state of the mother and its 'inheritance' is consequently maternal.

Further evidence of maternal effects is seen in the mean litter size which is reduced in histidinaemic mothers to about $67 \%$ of the normal at birth (Table VII). There is further reduction up to weaning, but thereafter no differential lethality occurs. Histidinaemic mothers also exert a deleterious influence on the development of their surviving offspring. This is reflected in the weights and in the weight gains up to the age of weaning. Table VIII gives the mean weights (of about 15 animals in

TABLE VII

Mean litter size at various ages

\begin{tabular}{|c|c|c|c|c|}
\hline \multirow{2}{*}{ Matings } & \multirow{2}{*}{ No. of litters } & \multicolumn{3}{|c|}{ Mean litter size at } \\
\hline & & Birth & Weaning ( 3 wk) & 7 wk \\
\hline $\begin{array}{c}\text { Histidinaemic females } \\
\text { and } \\
\text { histidinaemic males } \\
\text { Heterozygous females } \\
\text { and } \\
\text { heterozygous males }\end{array}$ & 15 & $\begin{array}{l}6 \cdot 1 \\
9 \cdot 3\end{array}$ & $\begin{array}{l}4 \cdot 7 \\
8 \cdot 7\end{array}$ & $4 \cdot 1$ \\
\hline \multicolumn{2}{|c|}{ Difference } & $P \begin{array}{l}3 \cdot 2 \\
P<0.01\end{array}$ & $P \begin{array}{l}4.0 \\
<0.01\end{array}$ & $\begin{array}{c}4.0 \\
P<0.001\end{array}$ \\
\hline
\end{tabular}

TABLE VIII

Comparison of mean weights $(\mathrm{g})$ of offspring at different ages from normal and histidinaemic parents

\begin{tabular}{|c|c|c|c|c|c|}
\hline \multirow[b]{3}{*}{ Tissue histidine levels of offspring } & \multicolumn{5}{|c|}{ Type of mating } \\
\hline & \multicolumn{3}{|c|}{ Heterozygous mother and heterozygous father } & \multicolumn{2}{|c|}{ Histidinaemic mother and histidinaemic father } \\
\hline & Normal & & High & High & High \\
\hline Behaviour of offspring & Normal & & Normal & Affected & Normal \\
\hline $\begin{array}{l}\text { Weights of female offspring (g) } \\
3 \mathrm{wk} \\
7 \mathrm{wk}\end{array}$ & $\begin{array}{r}8 \cdot 7 \\
16 \cdot 6\end{array}$ & & $\begin{array}{r}8 \cdot 8 \\
17 \cdot 0\end{array}$ & $\begin{array}{r}6 \cdot 4 \\
14 \cdot 9\end{array}$ & $\begin{array}{r}8 \cdot 1 \\
17 \cdot 4\end{array}$ \\
\hline $\begin{array}{l}\text { Weights of male offspring (g) } \\
3 \mathrm{wk} \\
7 \mathrm{wk}\end{array}$ & $\begin{array}{r}9 \cdot 0 \\
21 \cdot 6\end{array}$ & & $\begin{array}{r}9 \cdot 8 \\
21 \cdot 9\end{array}$ & $\begin{array}{r}5.9 \\
16.0\end{array}$ & $\begin{array}{r}7 \cdot 8 \\
19 \cdot 5\end{array}$ \\
\hline
\end{tabular}


each class) from two types of matings, one producing only histidinaemic offspring, the other segregating for histidinaemics and normals. It will be noted that the latter show little difference in either 3-week (weaning) or 7-week weight, having been born from normal (though heterozygous) mothers. Offspring from homozygous histidinaemic mothers on the other hand, have very much lower 3-week weights. This difference is greater in the animals with balance defects. There is a 'recovery' between 3 and 7 weeks.

\section{Vestibular damage}

We have as yet not been in a position to test the extent of any neurological functional damage of offspring born of histidinaemic mothers. There appears to be no histologically detectable abnormality in the brain cellular morphology (examined by Dr. H. Fraser). As far as the balance defect is concerned, the nature of the maternal influence appears to be damage to the inner ear. Four classes of animals were examined by dissection of the fixed inner ears. The results are shown in Table IX. All animals in (a) were matings of

TABLE IX

Maternal genotype and vestibular damage

\begin{tabular}{|c|c|c|c|c|c|}
\hline \multirow{2}{*}{ No. } & \multirow{2}{*}{$\begin{array}{l}\text { Offspring } \\
\text { genotype }\end{array}$} & \multirow{2}{*}{$\begin{array}{c}\text { Plasma } \\
\text { histidine }\end{array}$} & \multirow{2}{*}{ Behaviour } & \multicolumn{2}{|c|}{$\begin{array}{l}\text { Damage to inner } \\
\text { ears }\end{array}$} \\
\hline & & & & Left & Right \\
\hline \multicolumn{4}{|c|}{ (a) Offspring of histidinaemic mothers } & & \\
\hline 1 & his/his & High & Normal & Mild & Mild \\
\hline 2 & his/his & High & Normal & Mild & 一 \\
\hline 3 & his/his & High & Normal & Normal & Normal \\
\hline 4 & his/his & High & Affected & Severe & Severe \\
\hline 5 & his/his & High & Affected & Severe & Severe \\
\hline 6 & his/his & High & Affected & - & Severe \\
\hline 7 & his/his & High & Affected & Severe & Severe \\
\hline \multicolumn{6}{|c|}{ (b) Offspring of heterozygous mothers } \\
\hline 8 & his/his & High & Normal & - & Normal \\
\hline 9 & his/his & High & Normal & Normal & Normal \\
\hline 10 & his/his & High & Normal & Normal & - \\
\hline 11 & $+1 ?$ & Normal & Normal & Normal & Normal \\
\hline 12 & $+1 ?$ & Normal & Normal & Normal & Normal \\
\hline 13 & $+1 ?$ & Normal & Normal & Normal & Normal \\
\hline
\end{tabular}

histidinaemic females by histidinaemic males, and therefore are genotypically homozygous mutants showing high histidine in the tissues. On behavioural scoring, 3 were found to be normal and 4 affected. The ears were examined by Dr. Mary Lyon for abnormalities of otoliths, canals, and pigmentation and classified for 'normal', 'mild', or 'severe' effects. These were a shortening of the posterior vertical canal and the crus commune, the absence or greatly reduced otoliths in one or both ears, and a reduction in the pigmentation. It can be seen that balance-affected animals had severe vestibular damage. 2 out of the 3 animals classified as behaviourally normal nevertheless showed mild damage. The threshold for overt behavioural abnormality, therefore, appears to be higher than the structurally detectable damage.

The animals in (b) (Table IX) were from matings of heterozygous females by heterozygous males and therefore fell in two genotypic classes: mutant homozygotes (his/his) with high histidine and heterozygotes, or normal homozygotes $(+/$ ?) with normal tissue histidine. As already shown in Table $\mathrm{V}$, all were behaviourally normal irrespective of genotype. No defects were detected in any of the inner ears.

The vestibular damage would, of course, not explain the greater lethality or growth retardation and may perhaps be considered an indicator of other teratogenic or developmental effects of the in utero exposure of the embryo.

\section{Comparison of maternal effects}

While we are satisfied that histidinaemic mouse and man are homologous at the genetic, enzymic, and metabolic levels, the identification of the mouse behavioural syndrome with human mental retardation is subject to severe qualifications. In the first place no balance defects have been reported in man (Neville et al., 1972). Secondly, IQ measurements are probably not strictly comparable to any tests available on animals.

It is nevertheless useful to view the mouse syndrome in the light of human metabolic disorders, particularly since it is known that in one of these a strong maternal effect is displayed. This is phenylketonuria where the pathway affected is very similar to that of histidine (Fig. 5). Many steps of the two pathways are identical except for the substitution of the phenyl ring for the imidazole ring. Phenylketonurics (homozygous for a recessive gene) are mentally retarded unless treated early in life with a low phenylalanine diet. There is, in addition, a considerable risk of a heterozygote being mentally affected if the mother is a phenylketonuric (Dent, 1957; Denniston, 1963). There is some evidence that this risk is greater with increasing urine phenylpyruvic acid (Auerbach, DiGeorge, and Carpenter, 1967). Successful dietary management of phenylketonuric mothers during pregnancy has produced normal children (Allen and Brown, 1968).

The lack of reports of a similar maternal effect in human histidinaemia seems to distinguish this disorder from phenylketonuria. Furthermore, the existence of a high proportion of mentally normal 


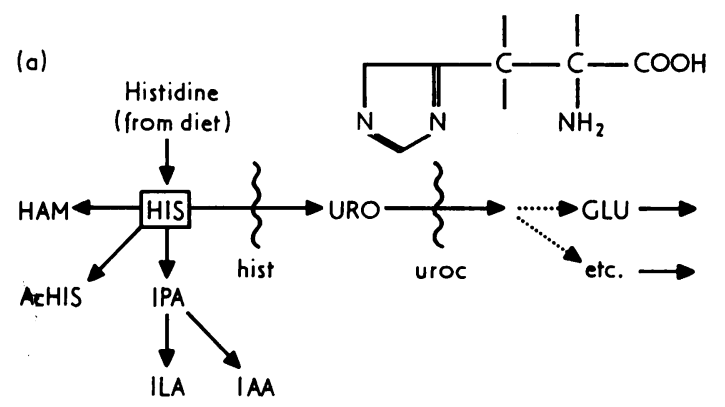

(b)

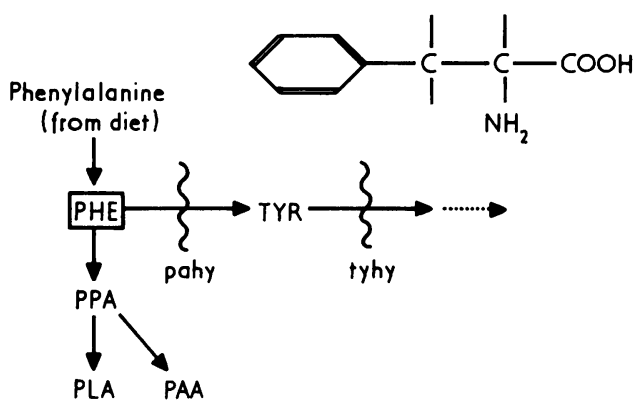

FIG. 5.-Catabolic pathways of histidine and phenylalanine. (a) HAM, histamine; AcHIS, N-acetylhistidine; HIS, histidine; URO, urocanic acid; IPA, imidazole pyruvic acid; ILA, imidazole lactic acid; IAA, imidazole acetic acid; GLU, glutamic acid; hist, histidase; uroc, urocanase. (b) PHE, phenylalanine; TYR, tyrosine; $P P A$, phenylpyruvic acid; PLA, phenyl-lactic acid; $P A A$, phenylacetic acid; pahy, phenylalanine hydroxylase; tyhy, tyrosine hydroxylase.

histidinaemics suggests a much lower penetrance of mental retardation than is the case in phenylketonuria. An explanation has been put forward by Neville et al. (1971).

'Blood histidine is lower in histidinaemia than phenylalanine in phenylketonuria, due perhaps to the lower histidine content of dietary protein, higher renal clearance of histidine, or increased efficiency of alternative pathways (Seakins and Holton, 1969). This may account for the lower incidence of mental retardation observed in histidinaemia. The risk in maternal histidinaemia would also be expected to be lower than in maternal phenylketonuria.'

An additional reason may be found in the relatively recent recognition of the condition, which in turn may partly be due to the low risk of mental disorder. One case of normal offspring from a histidinaemic mother has been reported (Neville et al., 1971), but so far little opportunity exists to ascertain whether histidinaemic mothers can produce any mentally retarded offspring. Similarly, no attempt appears to have been made to ascertain how many mothers of mentally retarded children are histidinaemic or suffering from other metabolic disorders. Such an investigation is now being undertaken. That this is worth pursuing is indicated by the report of Arthur and Hulme (1970) of the detection and successful dietary management of an undiagnosed case of phenylketonuria by routine Phenistix testing in an antenatal clinic. Our findings of a maternal effect in the mouse syndrome suggests that maternal histidinaemia may constitute a similar risk. Such mothers would also be detected by the Phenistix (though not by the specific PKU Guthrie test) and certainly by chromatographic screening. In view of the high incidence of about 1:11,000 for histidinaemia (Lott, Wheelden, and Levy, 1970; Raine et al., 1972), a study of the urinary metabolites of mothers with mentally retarded children may contribute towards the prevention of some maternally caused disorders. Dietary management of these mothers during pregnancy could be more important than the treatment of the offspring.

We are greatly indebted to Dr. Margaret E. Wallace for providing us with animals to screen her mutant stocks and for her continuing interest in the histidinaemic strain. We received valuable assistance from Mrs. E. Milligan, Mrs. K. Henderson, Mrs. L. Mackintosh, Mrs. L. McIntyre, Mrs. P. Leith, Mrs. E. Moore, Miss L. Ruthven, and Miss $\mathrm{K}$. Andrews. This research project is supported by the M.R.C.

\section{REFERENCES}

Allen, J. D., and Brown, J. K. (1968). Maternal phenylketonuria and foetal brain damage. In Some Recent Advances in Inborn Errors of Metabolism, p. 14. Ed. by K. S. Holt and V. P. Coffey. Livingstone, Edinburgh.

Arthur, L. J. H., and Hulme, J. D. (1970). Intelligent, small for dates baby born to oligophrenic phenylketonuric mother after low phenylalanine diet during pregnancy. Pediatrics, 46, 235.

Auerbach, V. H. DiGeorge, M. D., and Carpenter, G. C. (1967) Histidinemia. In Amino Acid Metabolism and Genetic Variation, p. 145. Ed. by W. L. Nyhan. McGraw-Hill, New York.

Coleman, D. L. (1962). Effect of genic substitution on the incorporation of tyrosine into the melanin of mouse skin. Archives of Biochemistry and Biophysics, 96, 562.

Denniston, J. C. (1963). Children of mothers with phenylketonuria. Fournal of Pediatrics, 63, 461.

Dent, C. E. (1957). Discussion of Armstrong, M.D. Relation of biochemical abnormality to the development of mental defect in phenylketonuria. In Etiologic Factors in Mental Retardation, p. 32. Report of twenty-third Ross Pediatric Research Conference, 1956. Ross Laboratories, Columbus, Ohio.

Elftman, H., and Wegelius, O. (1959). Anterior pituitary cytology of the dwarf mouse. Anatomical Record, 135, 43.

Feinstein, R. N. (1970). Acatalasemia in the mouse and other species. Biochemical Genetics, 4, 135.

Ghadimi, H., Partington, M. W., and Hunter, A. (1961). A familial disturbance of histidine metabolism. New England fournal of Medicine, 265, 221. 
Green, E. L. (Editor) (1966). Biology of the Laboratory Mouse, 2nd ed. McGraw-Hill, London.

Hague, R. V., and Holton, J. B. (1971). An intravenous histidine load test for the detection of heterozygotes for histidinaemia. Clinica Chimica Acta, 33, 462.

Harris, H. (1970). The Principles of Human Biochemical Genetics, p. 174. North-Holland, London.

Huijing, F. (1970). Phosphorylase kinase deficiency. Biochemical Genetics, 4, 187.

Kacser, H., Bulfield, G., and Wallace, M. E. (1973). Histidinaemic mutant in the mouse. Nature, 244, 77.

Kacser, H., and Burns, J. (1973). The control of flux. In Rate Control of Biological Processes, p. 65 . Ed. by D. D. Davies. Society for Experimental Biology, Symposium No. 27. Cambridge University Press, London.

Lott, I. T., Wheelden, J. A., and Levy, H. L. (1970). Speech and histidinemia: methodology and evaluation of four cases. Developmental Medicine and Child Neurology, 12, 596.

McKusick, V. A. (1971). Mendelian Inheritance in Man. Catalogs of Autosomal Dominant, Autosomal Recessive, and $\mathrm{X}$-linked Phenotypes, 3rd ed. Johns Hopkins Press, Baltimore and London.

Mayer, J. (1960). The obese-hyperglycemic syndrome of mice as an example of 'metabolic' obesity. American fournal of Clinical Nutrition, 8, 712 .

Neville, B. G. R., Bentovim, A., Clayton, B. E., and Shepherd, J.
(1972). Histidinaemia. Archives of Disease in Childhood, 47, 190.

Neville, B. G. R., Harris, R. F., Stern, D. J., and Stern, J. (1971) Maternal histidinaemia. Archives of Disease in Childhood, 46, 119.

Padgett, G. A., Reiquam, C. W., Gorham, J. R., Henson, J. B., and O'Mary, C. C. (1967). Comparative studies of the ChediakHigashi syndrome. American fournal of Pathology, 51, 553.

Raine, D. N. (1972). Management of inherited metabolic disease British Medical fournal, 2, 329.

Raine, D. N., Cooke, J. R., Andrews, W. A., and Mahon, D. F. (1972). Screening for inherited metabolic disease by plasma chromatography (Scriver) in a large city. British Medical Fournal, 3, 7 .

Seakins, J. W. T., and Holton, J. B. (1969). Histidinaemia. Biochemical fournal, 111, 4P.

Searle, A. G. (Editor) (1973). Mouse News Letter, No. $49 . \quad$ M.R.C. Laboratory Animals Centre, Carshalton, Surrey.

Wallace, M. E. (1970). Anomalies in Peru mice; origins of the other three wild stocks; polymorphism in four wild stocks. Mous News Letter, 42, 20.

Correspondence to Dr. H. Kacser, Institute of Animal Genetics, University of Edinburgh, West Mains Road, Edinburgh EH9 3JN. 